
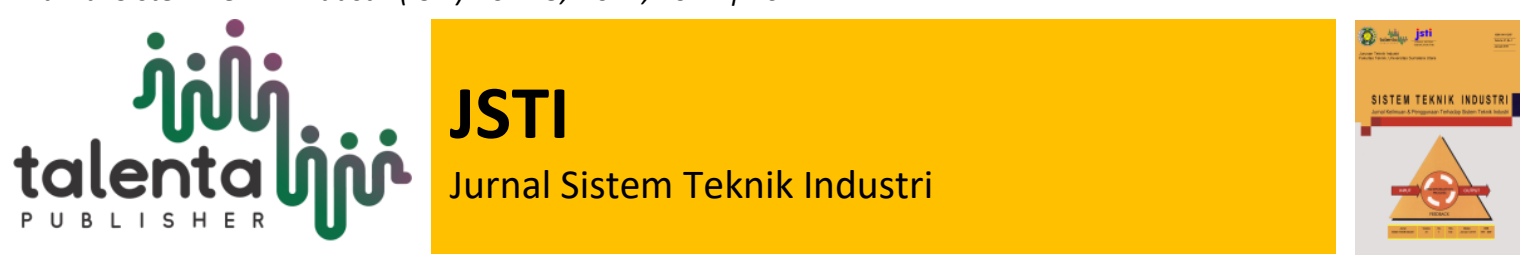

\title{
Need Identification on Android-Based Neighborhood Electric Vehicle Dashboard View Using The Kano Model
}

\author{
Nurhikmah Fajar', Muh Arif Wibisono ${ }^{2}$, Enas Dhuhri Kusuma ${ }^{3}$ \\ ${ }^{1,2}$ Mechanical and Industrial Engineering Department, Gadjah Mada University \\ ${ }^{3}$ Electrical Engineering dan Information Technology Department, Gadjah Mada University
}

\begin{abstract}
A customer is someone who repeatedly comes to the same place when he wants to buy an item or get service because he is satisfied with the goods or services. Companies must understand the needs and desires of customers in order to satisfy customer needs. Technology that is currently developing is electric cars, especially the Neighborhood Electric Vehicle (NEV) with the application of smartphones. Conventional dashboards can be replaced with smartphones Android-based. Fulfillment of customer satisfaction with smartphone dashboard products is identified by conducting a customer desires survey and categorized it using the Kano model. The survey was conducted on 14 attributes by producing three categories, such as one dimensional, attractive and indifferent. The Android dashboard is built based on survey results instruments. The use of Arduino nano and ESP32 as controllers that process vehicle instrument data sent using Wi-Fi in real time to Android-based smartphones has a maximum error of $5 \%$ for speed data.
\end{abstract}

Keyword: Needs, Kano model, NEV, dashboard, Android

\begin{abstract}
Abstrak. Pelanggan merupakan seseorang yang secara berulang-ulang datang ke tempat yang sama ketika ingin membeli suatu barang atau memperoleh jasa karena merasa puas dengan barang maupun jasa. Salah satu cara untuk mencapai kesuksesan suatu produk adalah dengan memahami kebutuhan dan keinginan pelanggan. Saat ini teknologi kendaraan mobil listrik khusus Neighborhood Electric Vehicle (NEV) dan pengaplikasian smartphone tengah berkembang. Dasbor kendaraan yang sifatnya konvensional dapat digantikan dengan smartphone berbasis Android. Pemenuhan kepuasan pelanggan terhadap produk dasbor smartphone diidentifikasi terlebih dahulu dengan melakukan survei keinginan pelanggan yang kemudian dikategorisasikan menggunakan model Kano. Survei dilakukan pada 14 atribut dengan menghasilkan sebanyak tiga kategori yaitu one-dimentional, attractive dan indiferrent. Dasbor Android yang dibangun memuat instrumen hasil survei. Penggunaan Arduino nano dan ESP32 sebagai kontroler yang mengolah data instrumen kendaraan dengan dikirim menggunakan Wi-Fi secara realtime menuju smartphone berbasis Android. Sistem ini memiliki selisih maksimum untuk data kecepatan sebesar 5\%.
\end{abstract}

Kata Kunci: Kebutuhan, model Kano, NEV, dasbor, Android

Received 09 June 2021 | Revised 01 July 2021 | Accepted 15 July 2021

${ }^{*}$ Corresponding author at: Universitas Gadjah Mada, Daerah Istimewa Yogyakarta, 55281, Indonesia 


\section{Introduction}

The customer is one important component in the buying and selling process. According to Rambat and Hamdani [1], a customer is someone who repeatedly comes to the same place when he wants to buy an item or obtain a service because he is satisfied with the goods or services. the customer as the end-user of the product is referred to as a real customer [2]. According to Van Kleef et al., [3] to achieve the success of a product, companies must understand the needs and desires of customers which are called the voice of customers. Understanding the attributes of a product or service that are acceptable and affect consumers will save a lot of expenditure and energy for the provision of products or services and can determine better strategies to achieve maximum results (Berger et al., 1993) [4]. One reason behind new product development is technologies and markets. Product development will follow the wishes of customers that are adjusted to the standards and available manufacturing facilities.

The electric car is a technology in four-wheeled vehicles that utilizes a power source as fuel and an electric motor as the driving force. One type of electric vehicle is the Neighborhood Electric Vehicle (NEV). The NEV cannot be separated from the dashboard panel as in other public vehicles, but the electronic units or electronic instruments on the NEV less than other public cars so the instruments are not much to be displayed. According to Marques et. al., [5] dashboard panel is a fundamental component in every vehicle. The dashboard panel provides information to the driver about the vehicle's current status.

Conventional dashboard panels are mostly used lately. Conventional dashboards are still mechanical and embedded causing low flexibility. In addition, the mechanical dashboard requires a large amount of energy that is not compensated with a vehicle battery capacity that is limited. According to Scott et al., [6] dashboards have flexible not only classic components, such as speedometer, fuel level, indicator, and RPM (Revolution Per Minute) but also can monitor the battery, alerting the driver in case of errors that can increase the safety level. Safety is meant not only for the driver but also for protecting all electrical and electronic components in an electric vehicle. Apart from electric vehicles smartphones are one of the rapidly growing media, especially Android-based. Smartphones are one of the electronic media that is widely applied to vehicles, such as entertainment media. Technology development of smartphones allows wider and flexible use.

In addition to flexibility, a consideration in dashboard installation is effectiveness. The level of effectiveness of the electric car dashboard is determined by the selection of communication between the interface devices with the electric car electronic system. Communication or data transmission between the hardware contained in the car's electronic system and software has been widely used for wireless communication, such as using Wi-Fi and Bluetooth. The benefits of using Wi-Fi technology are increased work efficiency and allow us to use one device that is connected to the network together in a network area [7]. Wi-Fi technology is also based on the popular IEEE 802.11 specification with speeds of $11 \mathrm{Mbit} / \mathrm{sec}, 54 \mathrm{Mbit} / \mathrm{sec}$ which are 2 types of coverage smaller than $11 \mathrm{Mbit} / \mathrm{sec}$ [8]. Controlling vehicle instrument data that will be sent to the 
dashboard panel is using a microcontroller. Research (Perisoara, Sacaleanu and Vasile, 2017) used two different microcontrollers to achieve the monitoring of electric vehicles [9].

The challenge in building a dashboard panel is to combine all functions and information while keeping the display simple, efficient, safe, and promoting an excellent driver experience [10].

This paper aims to identify and realize the need for an environmental electric vehicle dashboard display using smartphones. Currently, vehicle instrument data transmission has been widely used for wireless data transmission (wireless) such as Wi-Fi. The use of Wi-Fi as a data transmission facility will make the data transmission process more efficient because the process is fast and has a wide range.

\section{Methodology}

\subsection{Identification of Needs}

Customer preferences can be map using the Kano model. Kano model is a model that aims to categorize the attributes of products and services based on how well the product or service is acceptable and satisfying customer needs. Research to find the features needed in car modification so they can determine the priority scale needed [11]. Mapping the fulfillment of customer needs for a developed product can be seen in the following figure [12].

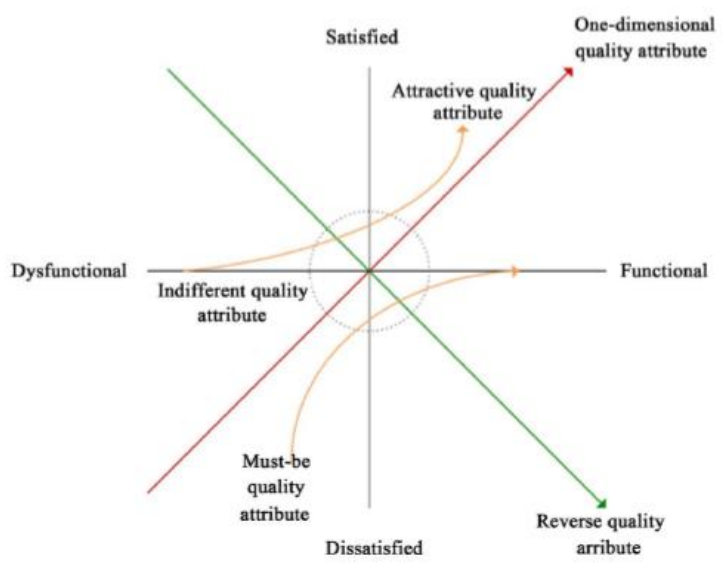

Figure 1 Kano Model Diagram

Figure 1 above shows a depiction of the Kano model with vertical and horizontal axes. The level of customer needs that meets the product aspect is shown on the horizontal axis, while the level of developed product capability that meets customer satisfaction is shown on the vertical axis. According to Tan and Pawitra [13] the Kano model has three main requirements categories that must be met by a product, i.e must be requirements (requirements must be met to make customers interested and satisfied with the product), the one-dimensional requirement (a requirement that really needs to be considered because it will affect customer satisfaction) and attractive requirement (requirement that if not met on a product it will not pose a risk of dissatisfaction by customers). Indifferent requirements and reverse requirements are not prioritized. 
The research initial stage is to survey on the attributes of vehicle instrument requirements on the dashboard display, which can be seen in Table 1 below. From the 14 attributes obtained, it was continued by conducting a follow-up survey to determine customer priority needs by giving positive questions that were functional product requirements and negative questions that were dysfunctional. These questions are processed using the Kano model. The survey was conducted by four-wheeled vehicle drivers who use smartphones Android-based.

Table 1 Need Attributes

\begin{tabular}{|c|c|c|c|}
\hline No. & Attributes & No. & Attributes \\
\hline 1. & Android dashboard & 8. & Battery power information feature \\
\hline 2. & Vehicle instrument detail viewing feature & 9. & Battery power warning feature \\
\hline 3. & Vehicle speed information feature $(\mathrm{km} / \mathrm{h})$ & 10. & $\begin{array}{l}\text { Battery temperature information } \\
\text { feature }\end{array}$ \\
\hline 4 & $\begin{array}{l}\text { Engine rotating speed (RPM) information } \\
\text { feature }\end{array}$ & 11. & Light information feature \\
\hline 5. & Vehicle mileage $(\mathrm{km})$ information feature & 12. & Turn signal information feature \\
\hline 6. & $\begin{array}{l}\text { Engine/motorcycle engine temperature } \\
\text { information feature }\end{array}$ & 13. & Hazard information feature \\
\hline 7. & $\begin{array}{l}\text { Vehicle maximum speed warning } \\
\text { information feature }\end{array}$ & 14. & Seat belt information feature \\
\hline
\end{tabular}

The final evaluation result of the Kano Model used in Blauth's formula is the maximum value (O, A, M) should be adopted if $(\mathrm{O}+\mathrm{A}+\mathrm{M})>(\mathrm{I}+\mathrm{R}+\mathrm{Q})$, otherwise $(\mathrm{I}+\mathrm{R}+\mathrm{Q})$ should be used. If two frequency requirements result are the same, the classification follows priority $\mathrm{M}>\mathrm{O}>\mathrm{A}$ to get the largest impact classification on the product. If the number of values $(\mathrm{O}+\mathrm{A}+\mathrm{M})=$ the number of values $(\mathrm{I}+\mathrm{R}+\mathrm{Q})$ then the grade is obtained the most the maximum among all Kano categories is $(\mathrm{O}, \mathrm{A}, \mathrm{M}$, and $\mathrm{I}, \mathrm{R}, \mathrm{Q})$.

\subsection{Neighborhood Electrical Vehicle}

Neighborhood electric vehicles (NEV) are categorized as batteries based vehicle with a top speed of $40 \mathrm{~km} / \mathrm{hour}$ and a maximum weight of $1400 \mathrm{~kg}$. However, NEV top speed depends on the country's regulation, so it will vary from one to another. Speed limits are applied because these vehicles are not designed to provide real protection for accidents. Due to its performance limitation, this small battery-powered vehicle is restricted to roads with a certain speed limit. NEV is a vehicle that is built to accommodate two people up to six seats

\subsection{Car Dashboard Design Identifikation}

According to Francois et al [14] Car dashboard design consists of information to be presented to the driver, how the information is displayed and when it should be displayed to determine the 
logic of human interaction with the captured vehicle information. Other things to consider in the dashboard design are the size of the screen, universal icons size, cluster instrument display, and the interface especially when used. In this study, the screen size is not specified because the application software can adjust to the departing size.

\subsection{Microcontroller}

The microcontroller in Figure 2 is used to controlling the input and output of NEV instruments in Android-based smartphones application. In this study, the ESP32 microcontroller module equipped with Bluetooth and Wi-Fi modules is used. Nano Arduino is used to read the input and output of vehicle instruments.

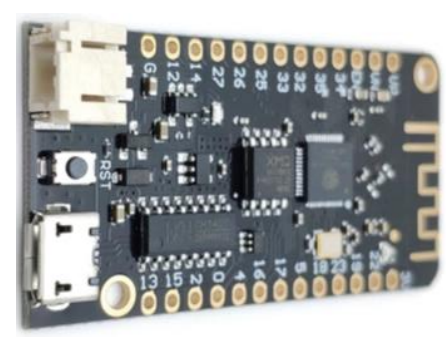

(a) EP32

Figure 2 Microcontroller

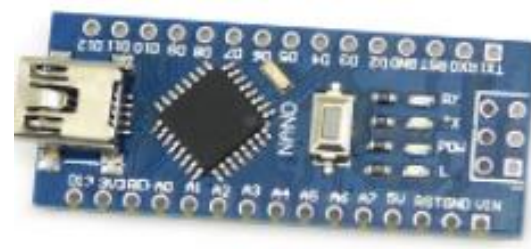

(b) Arduino nano

In this study used, Wi-Fi is used for data communication so it becomes efficient. This module is also equipped with a lipo battrey socket so it can take an external power resource which can minimize electrical energy in the car battery.

\subsection{Research Methods}

The preliminary study of this research includes literature study, observation and is the initial process of collecting information, theory, and literature that can assist in the system development process. The literature that is used is related to the preferences of customer needs for a product, methods of making dashboards (esp. electronic dashboards), programming concepts in Android platforms, and microcontrollers.

Data collection is carried out by distributing questionnaires to 70 respondents. The respondent's criteria are being able to drive car and android-based smartphone users and observing the dashboard display on environmental electric vehicles. Needs identification for the dashboard display was performed by distributing questionnaires to respondents in the form of functional and dysfunctional questions. In addition, interviews were conducted with related parties regarding the design of the dashboard device and the dashboard display application in order to obtain a solution for tool design. Final results of the designed tool expected to be able to provide solutions to problems and meet or adjust the needs of the users of the tool [15].

The next research step is dashboard system design. The design step is carried out by referring to the results of the identification of customer needs as a proposal in the manufacture or development 
of the product to be made. The dashboard work system design that will be built can be seen in Figure 3.

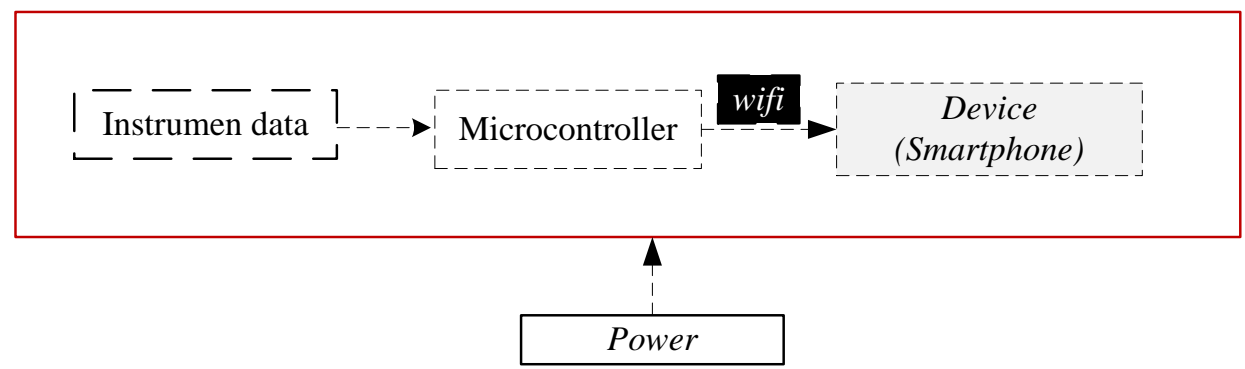

Figure 3 Dashboard Block Diagram

After collecting data and system design, data processing is carried out based on the questionnaires that have been distributed. Later, and the device that has been built implemented and tested.

\section{Result and Discussion}

\subsection{Kano Model Evaluation}

Results of identifying customer needs for the dashboard display of an Android-based environmental electric vehicle using the Kano model by distributing questionnaires to 70 respondents by providing functional and dysfunctional questions on 14 attributes shown in Table 1. Table 2 shows the results of distributing questionnaires for each category of the existing attributes.

Table 2 The results of the Kano model evaluation table for each need

\begin{tabular}{|c|c|c|c|c|c|c|c|}
\hline No. & Attributes & $\mathrm{A}$ & $\mathrm{O}$ & $\mathrm{M}$ & $\mathrm{I}$ & $\mathrm{R}$ & Q \\
\hline 1. & Android dashboard & 43 & 1 & 0 & 22 & 1 & 3 \\
\hline 2. & $\begin{array}{l}\text { Detailed condition of each electronic } \\
\text { instrument view }\end{array}$ & 21 & 13 & 5 & 30 & 0 & 1 \\
\hline 3. & Vehicle speed information feature & 21 & 38 & 3 & 6 & 1 & 1 \\
\hline 4. & $\begin{array}{l}\text { Speed motor (RPM) information } \\
\text { feature }\end{array}$ & 22 & 14 & 3 & 28 & 1 & 2 \\
\hline 5. & Mileage information feature & 30 & 26 & 2 & 10 & 0 & 2 \\
\hline 6. & $\begin{array}{l}\text { Motor/engine temperature information } \\
\text { feature }\end{array}$ & 21 & 11 & 4 & 30 & 2 & 2 \\
\hline 7. & $\begin{array}{l}\text { Vehicle maximum speed warning } \\
\text { feature }\end{array}$ & 24 & 10 & 4 & 31 & 0 & 1 \\
\hline 8 . & Battery power information feature & 21 & 36 & 1 & 9 & 0 & 3 \\
\hline 9. & Battery power warning feature & 22 & 15 & 2 & 29 & 0 & 2 \\
\hline
\end{tabular}




\begin{tabular}{llllllll}
\hline No. & \multicolumn{1}{c}{ Attributes } & $\mathrm{A}$ & $\mathrm{O}$ & $\mathrm{M}$ & $\mathrm{I}$ & $\mathrm{R}$ & $\mathrm{Q}$ \\
\hline 10. & $\begin{array}{l}\text { Battery temperature information } \\
\text { feature }\end{array}$ & 22 & 11 & 0 & 33 & 2 & 2 \\
11. & Hazard information feature & 18 & 34 & 3 & 11 & 0 & 4 \\
12. & Lights information feature & 20 & 40 & 2 & 5 & 1 & 2 \\
13. & Turn signals information feature & 24 & 36 & 2 & 5 & 1 & 2 \\
14. & Seat belts information feature & 25 & 18 & 1 & 24 & 0 & 2 \\
\hline
\end{tabular}

Table 2 above shows the results of attribute categorization on the distribution by the Kano model questionnaire in each attribute. For each attribute, results are obtained in each category of One Dimensional (O), Attractive (A), Must be (M), Indifference (I), Reverse (R), and Questionable (Q). After classifying using the Kano model evaluation matrix, it was found that for attribute 1 there were 43 respondents included in the Attractive (A) category, 1 respondent included in the One Dimensional $(\mathrm{O})$ category, 22 respondents included in the Indifference (I) category, 1 respondent was included in Reverse category, and none of the respondents are included in Must be (M) category. Results obtained from each category from the questionnaire then calculated using Blauth's formula where Blauth's formula will determine the right category for each attribute by calculating the values $(\mathrm{O}+\mathrm{M}+\mathrm{A})$ and $(\mathrm{I}+\mathrm{R}+\mathrm{Q})$ on each attribute. The following Table 3 shows the results of calculations using Blauth's formula which also determines the category of each attribute.

Table 3 Kano Categorization Result

\begin{tabular}{lllll}
\hline No. & Attributes & $\mathrm{O}+\mathrm{A}+\mathrm{M}$ & $\mathrm{I}+\mathrm{R}+\mathrm{Q}$ & Category \\
\hline 1. & Android Dashboard & 44 & 26 & $\mathrm{~A}$ \\
2. $\quad \begin{array}{l}\text { Detailed condition of each electronic } \\
\text { instrument view }\end{array}$ & 39 & 31 & $\mathrm{~A}$ \\
3. $\quad$ Vehicle speed information feature & 62 & 8 & $\mathrm{O}$ \\
4. $\quad$ Speed motor (RPM) information feature & 39 & 31 & $\mathrm{~A}$ \\
5. $\quad$ Mileage information feature & 58 & 12 & $\mathrm{~A}$ \\
6. $\quad$ Motor/engine temperature information feature & 36 & 34 & $\mathrm{~A}$ \\
7. $\quad$ Vehicle maximum speed warning feature & 38 & 32 & $\mathrm{~A}$ \\
8. & Battery power information feature & 58 & 12 & $\mathrm{O}$ \\
9. & Battery power warning feature & 39 & 31 & $\mathrm{~A}$ \\
10. & Battery temperature information feature & 33 & 37 & $\mathrm{I}$
\end{tabular}




\begin{tabular}{llccc}
\hline No. & Attributes & $\mathrm{O}+\mathrm{A}+\mathrm{M}$ & $\mathrm{I}+\mathrm{R}+\mathrm{Q}$ & Category \\
\hline 11. & Hazard information feature & 55 & 15 & $\mathrm{O}$ \\
12. & Lights information feature & 62 & 8 & $\mathrm{O}$ \\
13. & Turn signals information feature & 62 & 8 & $\mathrm{O}$ \\
14. & Seat belts information features & 44 & 26 & $\mathrm{~A}$ \\
\hline
\end{tabular}

Table 3 above shows the results of Kano's model categorization on the fourteen attributes. There are 3 categories, namely one-dimensional (O), attractive (A), and indifferent (I). Attributes that fall into one-dimensional categories are attributes $(3,8,11,12$ and 13) which means that if these attributes are met, it will increase the level of customer satisfaction, vice versa. Attributes that fall into the attractive categories are attributes $(1,2,4,5,6,7,9$ and 14) which means if this category is fulfilled will increase the level of customer satisfaction, vice versa. Meanwhile, attribute 10 is included in the indifferent categories which is a need that is not prioritized or not. According to Parul [16], attributes that are included in the indifferent categories do not need further processing because they have a very low impact on customer dissatisfaction.

\subsection{Dashboard Display Result}

Based on several selected needs from one-dimensional and attractive categories, a dashboard display will be realized where the displayed feature will adjust to the instruments available on the NEV. Attributes of detailed features in the instrument, engine speed information, seat belt information, battery temperature, engine temperature are not embodied in the dashboard creation. The dashboard display is built using HTML and JavaScript programming. Here is the dashboard display result.

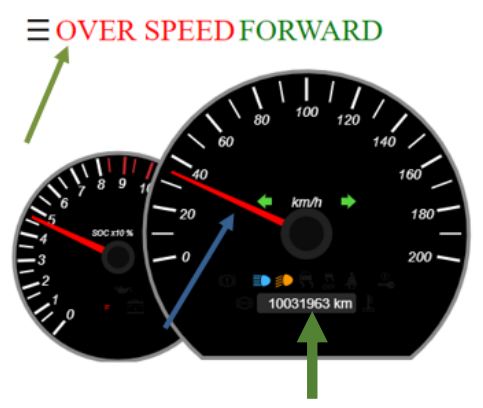

(a) warning, speed, mileage

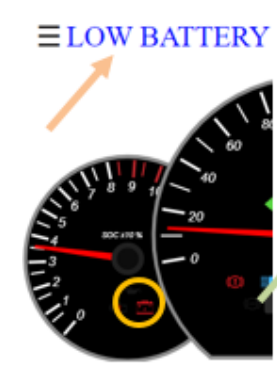

(b) battery power

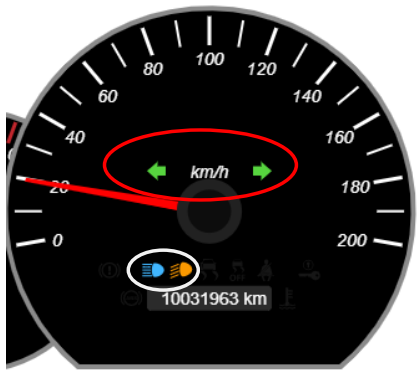

(c) light, turn signal, hazard

Figure 4 Dashboard Display Result

Needs that fall into the one-dimensional category embodied in the dashboard display include :

1. Vehicle speed: Indicated by the blue arrow (a), the vehicle speed feature is in units $(\mathrm{km} / \mathrm{h})$. 
2. Battery power: Show in the small circle on the left (b). The Battery power information feature will be show in percent (\%). The battery voltage value in the full condition is 55 volts, while the minimum condition for the vehicle battery to be charged is 43 volts or $78 \%$ of the full battery condition.

3. Lights: There are two features of vehicle lights (c). The near light (deep beam) is indicated by an orange light icon, and the high beam is indicated by a blue icon.

4. Hazard: Indicated by 2 arrow icons left and right (c). If this condition is activated, both the arrow will light up and blink.

5. Turn signal: This signal is shown the same as the hazard, namely the arrow (c). If this feature is activated (left or right turn signal) then one of the arrows will light up according to the activated signal.

Attractive categories are realized in the dashboard panel include:

1. Mileage: Indicated by the orange arrow (a). The vehicle mileage feature is given in $\mathrm{km}$.

2. Speed warning: The vehicle is set to only have a maximum speed of $20 \mathrm{~km} / \mathrm{h}$ so that if the vehicle speed is above $20 \mathrm{~km} /$ then an "OVER SPEED" notification will appear as indicated by a green arrow (a).

3. Battery power warning: and if the battery energy condition is below 78\% or the voltage value is 43 volts, a "LOW BATTERY" notification will appear on the top left, and the battery icon (see yellow circle) will light up (b). If the battery condition is above $78 \%$ the notification will disappear.

The Communication between hardware and software or applications using Wi-Fi. Before sending the NEV instrument data, the instrument data processing was carried out using the Arduino nano and ESP32 microcontrollers. The initial experiment was carried out using only 1 microcontroller, ESP32 by providing several digital inputs and analog inputs, however, after being given a digital input in the frequency form, ESP32 operation stop (stuck). Due to this condition, Arduino nano was added for reading and processing NEV instrument data. Data from Arduino nano will be sent to the ESP32, then sent to Android using Wi-Fi in real-time.

Vehicle speed data formed in frequency data $(\mathrm{Hz})$ issued by the vehicle instrument which is then converted into $\mathrm{km} / \mathrm{h}$ units. Vehicle speed data measured using a built microcontroller and an oscilloscope which is then compared to determine the value of the error or the difference. Measurements comparison can be seen in the following Figure 5. 


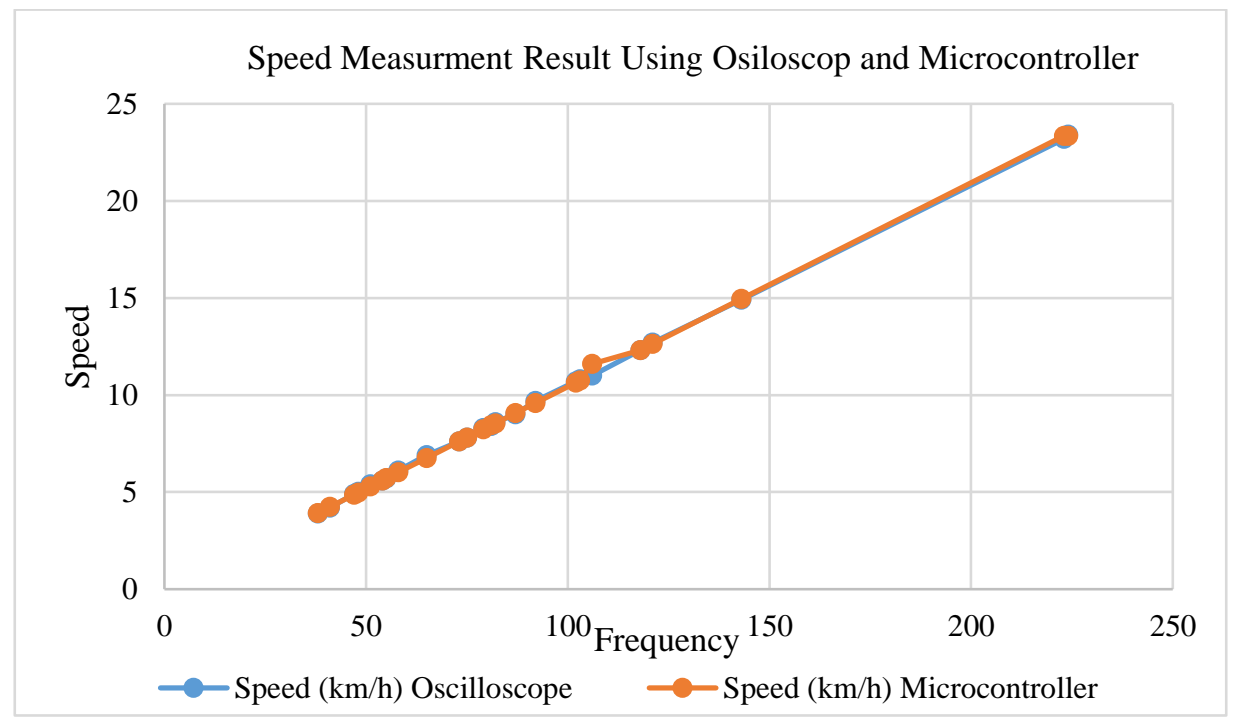

Figure 5 Speed Vehicle Measurement Comparison Result

The Frequency value from measurement results using microcontroller and oscilloscope is directly proportional to the speed, so if the frequency value increase, the vehicle speed will be faster. The more the source frequency increases the speed of the induction motor, the smaller the motor coil current and the efficiency of the motor. [17]. The maximum measurement difference using these two media is $5.17 \%$.

\section{Conclusion}

Customer preferences for the dashboard display features of environmental electric vehicles using the Kano model give result 14 attributes which are grouped into 3 categories, one-dimensional, attractive and indifferent. Customer needs embodiment in an android-based dashboard panel using an Arduino nano and ESP32 microcontroller with a Wi-Fi data transmission, so this data can be real-time displayed. The Maximum speed data difference is $5.17 \%$.

Suggestion: Further research is expected to involve electric car vehicle maintenance technicians in identifying vehicle instrument data needs and conducting dashboard displays ergonomics analysis.

\section{Acknowledgments}

Acknowledgments are given to all parties involved in this research and Engineering Faculty Gadjah Mada University for funding this research.

\section{REFERENCES}

[1] L. Rambat and A. Hamdani, Manajemen Pemasaran Jasa, Jakarta: Salemba Empat, 2006.

[2] V. Gaspersz, Total Quality Management, Jakarta: Gramedia Pustaka Utama, 2008. 
[3] E. Van Kleef, H. C. Van Trijip and P. Luning, "Consumer research in the early stages of new product development: A critical review of methods and techniques," Food Quality and Preference, vol. 16, no. 3, pp. 181-201, 2005.

[4] C. Berger, R. Blauth, D. Boger and C. Bolster, "Kano's Methods for Understanding Customer Define Quality," Journal if the Japanese Society for Quality, vol. 2, no. 4, pp. 136, 1993.

[5] L. Marques, V. Vasconcelos and P. Pedreiras, "A flexible dashboard panel for a small electric vehicle," in Proceedings of the 6th Iberian Conference on Information Systems and Technologies, CISTI 2011, 2011.

[6] G. Scott, S. Vunakece, D. Vosawale, M. Assaf and U. Mehta, "A flexible Dasboard Panel System for Electric Vehicle," WSEAS TRANSACTION on ELECTRONICS, vol. 10, pp. 3341, 2019.

[7] I. Winarti, "Pengaruh Area Hotspot (Wi-Fi) Bagi Pengguna Kebutuhan Infromasi Pemustaka di Kantor Perpustakaan Daerah Kabupaten Jepara," Universitas Diponegoro, Semarang, 2010.

[8] A. Suriyanto, "Tinjauan Teknis Teknologi Perangkat Wireless dan Satandar Keamanannnya," Jurnal Teknologi Informasi DINAMIK, vol. XI, no. 2, pp. 75-83, 2006.

[9] L. A. Perisoara, D. L. Sacaleanu and A. Vasile, "Instrument Clusters for Monitoring Electric Vehicle," 017 IEEE 23rd International Symposium for Design and Technology in Electronic Packaging, SIITME 2017, pp. 379-382, 2017.

[10] Z. Gibson, J. Butterfield and A. Marzano, "User-Centered Design Criteria in Next Generation Vehicle COnsoles," Procedia CIRP, vol. 55, pp. 260-265, 2016.

[11] R. N. Pratama, "Identifikasi Kebutuhan Fitur Aplikasi Modifikasi Mobil Dengan Menggunakan Model Kano," Universitas Islam Indonesia, Yogyakarta, 2018.

[12] J. Huang, "Application of Kano Model in Requirements Analysis of Y Company's Consulting Project," American Journal of Industrial and Business Management, pp. 910918, 2017.

[13] K. C. Tan and T. A. Pawitra, "TIntegrating SERVQUAL and Kano's Model Into QFD for Service Excellence Development," Managing Service Quality, vol. 11, no. 6, p. 418-430, 2001.

[14] M. Francois, F. Osiurak, A. Fort and P. Crave, "Usability and acceptance of truck dashboards designed by drivers: Two participatory design approaches compared to a usercentered design," International Journal of Industrial Ergonomics, vol. 81, no. 103073, pp. $1-13,2021$.

[15] H. M. Hainer and J. R. Wilson, Development of a Framework for Participatory Ergonomic, Nottingham: Institute for Occupational Ergonomics, 1998.

[16] G. Parul, Analysis of Customer Satisfaction of The Hotel Industry in India Using Kano Model \& QFD, Prayagraj: Motilal Nehru National Institute of Technology, 2011.

[17] Z. Anthony, "Pengaruh Perubahan Frekuensi dalam Sistem Pengendalian Kecepatan Motor Induksi 3-Fasa Terhadap Efiensi dan Arus Kumparan Motor," Jurnal Teknik Elektro ITP, vol. 1, no. 1, pp. 25-29, 2011. 